\title{
SLC3A2 wt Allele
}

National Cancer Institute

\section{Source}

National Cancer Institute. SLC3A2 wt Allele. NCI Thesaurus. Code C124116.

Human SLC3A2 wild-type allele is located in the vicinity of 11 q13 and is approximately 33

$\mathrm{kb}$ in length. This allele, which encodes 4F2 cell-surface antigen heavy chain protein, is involved in amino acid transport. 